ing blankets. If any of this equipment had been contaminated, the case-patient surgeries would be expected to have occurred in only one operating room, because this equipment was not moved from room to room; however, case-patient surgeries occurred in both operating rooms. In addition, no water from these sources comes in direct contact with the patient's bloodstream. Two environmental surveys, conducted by CDC and hospital personnel, failed to identify another source.

Samples from the water-disinfectant system grew only $P$ aeruginosa of a different serotype than case-patient isolates. However, our samples were taken 3 weeks after the last case-patient's surgery. If the tap water was contaminated intermittently with various common water organisms, it is not unexpected that we could not recover the identical case-patient organisms. Similarly, the negative results from the pressure-monitoring equipment are not unexpected. No cultures were obtained from in-use case-patient pressure-monitoring equipment or intravenous lines. Our results are consistent with intermittent contamination; even during the outbreak period, no more than two OHS patients developed GNB during any week.

While numerous epidemics of nosocomial BSI have resulted from contaminated quaternary ammonium solutions contacting pressure-monitoring equipment, our outbreak did not involve a contaminated quaternary ammonium solution, but rather resulted from direct water contamination. 1,6

Although one study demonstrated that nondisposable pressure-monitoring equipment can be prepared in central supply days before use without contamination, such a practice requires scrupulous attention to aseptic precautions and assumes the pressure-monitoring equipment will not be exposed to subsequent contamination. ${ }^{8}$ This outbreak underscores the importance of adhering to the CDC guidelines that pressure-monitoring (or other) equipment should not be assembled hours or days before the time of actual need nor prefilled with flush solution and stored, even to prepare for a possible emergency. ${ }^{9}$ Adherence to these guidelines may help prevent future outbreaks involving preassembled and preflushed patient equipment.

\section{REFERENCES}

1. Maki DG. Epidemic nosocomial bacteremia. In: Wenzel RP, ed. Handbook of Hospital-Acquired Infections. West Palm Beach, FL: CRC Press; 1981:371-512.

2. Knaus WA, Draper EA, Wagner DP, Zimmerman JE. APACHE II: a severity of disease classification system. Crit Care Med 1985:13:818-829.

3. Siegel S. Nonparametric Statistics for the Behavioral Sciences. New York, NY: McGraw-Hill; 1956:184.

4. Clark WA, Hollis DG, Weaver RE, Riley P. Identification of unusual pathogenic gram-negative aerobic and facultative anaerobic bacteria. Atlanta, GA: Centers for Disease Control; 1984.

5. Birnboim HC, Doly J. A rapid alkaline extraction procedure for screening recombinant plasmid DNA. Nucleic Acids Res 1979;7:1513-1523.

6. Weinstein RA, Emori TG, Anderson RL, Stamm WE. Pressure transducers as a source of bacteremia after open heart surgery: report of an outbreak and guidelines for prevention. Chest 1976;69:338-344.

7. Beck-Sague CM, Jarvis WR. Epidemic bloodstream infections associated with pressure transducers: a persistent problem. Infect Control Hosp Epidemiol 1989;10:54-59.

8. Tenold R, Priano L, Kim K, Rourke B, Marrone T. Infection potential of nondisposable pressure transducers prepared prior to use. Crit Care Med 1987;15:582-583.

9. Simmons BP. Guideline for prevention of infections related to intravascular pressure-monitoring systems. Am J Infect Control 1983;11:183-193.

\section{by Gina Pugliese, RN, MS Medical News Editor}

In a recent case heard by the US Occupational Safety and Health Review Commission, a judge ruled that a hospital that provided surgical masks rather than respirators for workers exposed to tuberculosis (TB) did not violate federal requirements.

In a 1992 case (Secretary of Labor $v$ Columbia Presbyterian Hospital, New York City), OSHA cited the hospital for not providing its employees with at least a dust-mist-fume (DMF) respirator, required at that time by OSHA's

\title{
OSHA Loses Respirator Case
}

Region II office. Judge Irving Sommer noted that, early in 1990, there was not clear, consistent guidance for the healthcare community from federal and state agencies regarding employee respiratory protection against TB. Further, Judge Sommer ruled that OSHA guidelines were not consistent with the recommendations of other governmental bodies in health care, noting that the $\mathrm{CDC} \mathrm{TB}$ guidelines did not specify a DMF respirator. The court ruled that the burden was on the Secretary of Labor to show that Columbia Presbyterian Hospital had noticed that surgical masks were not adequate protection and that the New York City hospital had taken adequate precautions at that time. The court noted the hospital's use of other recommended infection control measures, such as early identification of potential TB patients and negativepressure isolation rooms, as well as its comprehensive documentation of conversion rates, which all supported the efficacy of the respirators selected.

FROM: Secretary of Labor $v$ Columbia Presbyterian Hospital. OSHRC, No. 93-298. January 2, 1996. 